\title{
Penggulungan daun pada tanaman monokotil saat kekurangan air (Leaf rolling in monocotyledon plants under water deficit)
}

\author{
Nio Song $A i^{1)^{*}}$ dan Audry Agatha Lenak ${ }^{2)}$ \\ 1) Jurusan Biologi FMIPA Universitas Sam Ratulangi Manado, 95115 \\ 2) Alumni Jurusan Biologi FMIPA Universitas Sam Ratulangi Manado, 95115 \\ *Email korespondensi: nio_ai@yahoo.com \\ Diterima 28 Februari 2014, diterima untuk dipublikasikan 18 Juli 2014
}

\begin{abstract}
Abstrak
Penggulungan daun merupakan salah satu bentuk resistensi terhadap kekeringan atau lebih tepatnya mekanisme menghindari kekeringan pada tumbuhan monokotil. Mekanisme ini terjadi dengan cara menurunkan laju evapotranspirasi atau dengan meningkatkan absorpsi air pada tanah kering untuk mempertahankan potensial air daun tetap tinggi. Proses penggulungan daun ini berkaitan erat dengan peranan sel kipas. Pada saat kekurangan air, jumlah dan ukuran sel kipas meningkat, sehingga daun akan menggulung. Tingkat penggulungan daun dapat ditentukan secara visual berdasarkan sistem standar evaluasi untuk tanaman padi dengan memberi skor 1-9. Rendahnya tingkat penggulungan daun berkorelasi positif dengan meningkatnya potensial air daun.

Kata kunci: menghindari kekeringan, penggulungan daun
\end{abstract}

\begin{abstract}
Leaf rolling is one mechanism of drought resistance, i.e. drought avoidance. This mechanism was resulted from decreasing evapotranspiration rate or increasing water absorption in the dry soil to maintain high leaf water potential. The process of leaf rolling in monocotyledon was closely related to the activity of bulliform cells. The number and size of bulliform cells were increased under water deficit, so that leaf rolling occurred. Leaf rolling score (1-9) could be visually determined based on the system of standard evaluation in rice. The low leaf rolling score was positively correlated with high leaf water potential.

Keywords: drought avoidance, leaf rolling

\section{PENDAHULUAN}

Air merupakan kebutuhan pokok bagi semua tanaman dan bahan penyusun utama protoplasma sel. Tanaman selalu membutuhkan air selama siklus hidupnya, mulai dari masa perkecambahan sampai panen. Semua proses metabolisme pada tanaman membutuhkan air, oleh sebab itu jumlah pemakaian air oleh tanaman berkorelasi positif dengan produksi biomassa tanaman dan

hanya sebagian kecil air yang diserap akan ditranspirasikan melalui stomata (Harwati 2007).

Pemanasan global (global warming) menyebabkan terjadinya perubahan iklim (climate changes) yang secara langsung berpengaruh terhadap perubahan musim. Pergantian musim yang tidak menentu merupakan salah satu akibat perubahan iklim, seperti musim kemarau yang berkepanjangan yang
\end{abstract}


menurunkan ketersediaan air di dalam tanah. Salah satu bentuk dampak perubahan iklim adalah kekeringan akibat kekurangan air pada lahan pertanian.

Tanaman dikatakan mengalami kekurangan air pada saat ketersediaan air dari lingkungannya termasuk media tanam terbatas. Kurangnya suplai air di daerah perakaran dan permintaan air yang berlebihan oleh daun akibat laju absorpsi air adalah penyebab kekurangan air pada tanaman walaupun air tanah tersedia dengan cukup (Levitt 1980; Bray 1997).

Tanaman mempunyai mekanisme untuk mengkompensasi pengaruh cekaman yang merusak pada skala waktu yang berbeda, tergantung pada proses fisiologi yang dipengaruhi dan sifat cekaman. Menurut Haryati (2008) kekurangan air akan mengganggu aktivitas fisiologis maupun morfologis, sehingga mengakibatkan terhentinya pertumbuhan. Defisiensi air yang terus menerus akan menyebabkan perubahan irreversibel (tidak dapat balik) dan pada gilirannya tanaman akan mati.

Berbagai karakter morfologi, anatomi, fisiologi, biokimia dan genetika telah dievaluasi sebagai respon tanaman terhadap kekeringan akibat kekurangan air. Salah satu karakter morfologi yang dapat diamati pada tumbuhan monokotil saat kekurangan air adalah penggulungan daun. Penggulungan daun dapat memperkecil luas permukaan daun yang terpapar pada sinar matahari, sehingga mengurangi laju transpirasi pada tanaman. Berkurangnya laju transpirasi akan membantu tanaman untuk bisa bertahan dalam jangka waktu tertentu pada saat berkurangnya ketersediaan air di lingkungan. Berdasarkan pokok-pokok pikiran di atas, pembahasan dalam makalah ini akan difokuskan pada proses penggulungan daun sebagai respon tanaman pada saat mengalami kekeringan akibat kekurangan air.

\section{KEKERINGAN KEKURANGAN TANAMAN}

\section{AIR}

Lingkungan yang ekstrim dapat menimbulkan cekaman pada tanaman. Kekeringan sebagai salah satu cekaman abiotik pada tanaman dapat dibedakan menjadi kekeringan primer dan kekeringan sekunder. Kekeringan primer menunjukkan kekurangan air di lingkungan sekitar tanaman, sedangkan kekeringan sekunder diinduksi oleh keadaan dingin, pembekuan, panas atau kadar garam. Kondisi saat sel tanaman telah kehilangan air dan mempunyai tekanan turgor yang lebih rendah daripada nilai maksimumnya dinamakan kekeringan akibat kekurangan air (Darusman et al. 1991; Filter dan Hay 1991).

Pembatas utama pertumbuhan dan kesintasan (survival) pada tanaman adalah persediaan air yang tidak memadai. Laju pertumbuhan selsel dan efisiensi proses fisiologisnya mencapai tingkat tertinggi pada saat sel-sel tanaman berada dalam keadaan turgor maksimum. Pada kondisi tersebut sel-sel aktif melakukan pembelahan sel dan pembesaran sel. Kekeringan baik secara langsung maupun secara tidak langsung dapat mengakibatkan hambatan pertumbuhan, kematian, penimbunan protein dan toksin, kerusakan biokimia dan inaktivasi enzim (Nio et al. 1997)

Potensial air adalah kemampuan air untuk melakukan difusi yang menggambarkan status energi bebas air dalam sel atau jaringan tumbuhan 
(Salisbury dan Ross 1992). Kekeringan pada sel tanaman dibedakan dalam tiga tingkatan, yaitu:

a. Tingkat ringan: jika potensial air sel tanaman sedikit menurun sampai $-0,5 \mathrm{MPa}$;

b. Tingkat sedang: jika potensial air dalam sel tanaman menurun sampai antara $-0,5$ dan $-1,2 \mathrm{MPa}$ atau antara $-0,5$ dan $-1,5 \mathrm{MPa}$;

c. Tingkat berat: jika potensial air sel tanaman kurang dari $-1,5 \mathrm{MPa}$ (Fitter dan Hay 1991).

Kekeringan dari tingkat ringan sampai berat dapat menghambat pertumbuhan sel, sintesis dinding sel, pembentukan protoklorofil, kandungan nitrat reduktase, akumulasi asam absisat, kandungan sitokinin, membuka dan menutupnya stomata, asimilasi $\mathrm{CO}_{2}$, respirasi, akumulasi prolin dan gula pada tanaman ( Hsiao 1973 dalam Fitter dan Hay 1991).

Istilah kekeringan akibat kekurangan air pada tanaman dapat ditinjau dari aspek meteorologi, hidrologi, sosial ekonomi dan pertanian. Kekurangan air secara meteorologi berkaitan dengan rendahnya curah hujan dalam periode tertentu. Ditinjau dari aspek hidrologi, kekeringan ini berkaitan dengan rendahnya ketersediaan air di sungai, danau atau daerah aquifer yang dimanfaatkan untuk kepentingan irigasi, wisata maupun transportasi. Secara sosial ekonomi, kekeringan menggambarkan hubungan antara suplai dan kebutuhan air untuk berbagai kebutuhan sosial dan ekonomi (WMO 2006 dalam Tubur 2011). Kekeringan dalam ruang lingkup pertanian berkaitan dengan rendahnya ketersediaan air tanah yang mendukung pertumbuhan tanaman dan dapat diartikan sebagai penurunan potensial air tanah akibat evapotranspirasi di daerah perakaran yang mempengaruhi pertumbuhan dan produksi (Takane et al. 1995 dalam Tubur 2011).

\section{RESPONS TANAMAN AKIBAT KEKURANGAN AIR}

Mekanisme respon tanaman terhadap kekurangan air secara umum disebut resistensi tanaman terhadap kekurangan air. Jones et al (1981) mendefinisikan resistensi terhadap kekurangan air sebagai rentangan mekanisme pada saat tanaman bertahan di periode kekeringan. Selanjutnya Turner (1979) dan Cordon (1982) dalam Nio (2011) mendefinisikan resistensi terhadap kekurangan air sebagai kemampuan tanaman untuk tumbuh dan berproduksi secara optimal selama kekurangan air. Pakar agronomi sering kali menghubungkan resistensi terhadap kekurangan air dengan produktivitas dan produksi tanaman, sedangkan pakar ekologi lebih banyak mengaitkannya dengan kelulushidupan tanaman (Jones et al. 1981; Mitra 2001).

Resistensi tanaman terhadap kekurangan air dapat berupa drought escape, drought avoidance, drought tolerance dan drought recovery. Drought escape (tahan kekeringan) merupakan kemampuan suatu tanaman untuk menyelesaikan siklus hidupnya sebelum terjadi kekeringan yang cukup serius. Drought avoidance (menghindari kekeringan) berkaitan dengan kemampuan tanaman memelihara potensial air jaringan agar tetap tinggi walaupun tanaman tersebut berada pada kondisi kekurangan air (Jones et al. 1981; Jadid, 2007). Drought tolerance (toleransi terhadap kekeringan) memungkinkan tanaman untuk bertahan terhadap kekeringan pada potensial air jaringan yang rendah (Jones et al. 1981, Jordan et al. 1983). 
Nio dan Lenak, Penggulungan daun ... 51

\begin{abstract}
Sedangkan drought recovery (pemulihan pertumbuhan setelah melewati periode kekeringan) menunjukkan kemampuan tanaman untuk memperbaiki sistem metabolismenya akibat kekurangan air (Arrandeau 1989 dalam Tubur 2011). Jenis mekanisme resistensi terhadap kekeringan yang dapat dilakukan merupakan faktor bawaan dari tiap genotipe tanaman. Tidak ada batasan tegas antara drought avoidance dan drought tolerance sebagai mekanisme resistensi tanaman saat kekurangan air karena penyesuaian osmotik yang berkaitan dengan akumulasi solut untuk mempertahankan tekanan turgor sel terjadi dalam kedua mekanisme tersebut.

Kondisi pada saat tanaman tidak lagi mampu menyerap air dan menjadi layu disebut titik layu (wilting point). Respon titik layu dapat bersifat balik maupun tidak balik tergantung pada spesies. Kemampuan tanaman untuk tetap tumbuh saat pemberian air dilakukan setelah melewati periode kekeringan tertentu merupakan bentuk respon titik layu yang dapat balik. Layu permanen terjadi saat tanaman tidak dapat melakukan aktivitas tumbuh, daun tetap mengalami pelayuan walaupun telah diberikan air kembali (Hardjowigeno dan Widiatmaka 2007).
\end{abstract}

\section{PENGARUH KEKURANGAN AIR TERHADAP PENGGULUNGAN DAUN}

Gejala layu pada daun atau terjadinya dehidrasi pada daun menunjukkan adanya kekurangan air pada tanaman (Adisyahputra et al., 2011). Kekurangan air di daun menyebabkan sel-sel penjaga (guard cells) kehilangan turgor sebagai mekanisme kontrol sederhana untuk memperlambat transpirasi dengan menutup stomata. Pertambahan ukuran sel merupakan proses yang bergantung pada turgor sehingga menghambat pertumbuhan daun muda dan memperlambat perluasan permukaan daun (Campbell et al. 2012). Dehidrasi daun dapat diminimalkan dengan cara penurunan evapotranspirasi atau dengan peningkatan absorpsi air pada tanah kering. Pengurangan kehilangan air dapat dilakukan dengan cara penggulungan daun, penutupan stomata, penurunan potensial air daun (Adisyahputra et al. 2011), pengurangan luas daun, percepatan pengguguran daun yang selanjutnya akan mengurangi total fotosintesis dan produksi biomassa (Bouman dan Tuong 2001).

Proses pelayuan yang mengakibatkan penggulungan daun pada tanaman monokotil merupakan salah satu mekanisme tanaman menghindari kekeringan atau drought avoidance. Penggulungan daun (Gambar 1) berkaitan dengan kemampuan penyesuaian laju transpirasi untuk mempertahankan potensial air daun tetap tinggi pada saat kekurangan air. Daun yang menggulung menyebabkan luas permukaan daun yang tak terlindung menjadi lebih kecil sehingga transpirasi menurun. Penggulungan daun mengakibatkan penurunan indeks luas daun dan tingkat penerimaan cahaya yang selanjutnya akan menurunkan laju fotosintesis (Fitter dan Hay 1991; Bouman dan Tuong 2001; Kurniasih dan Wulandhany 2009; Campbell et al. 2012).

Tingkat penggulungan daun dapat ditentukan secara visual berdasarkan sistem standar evaluasi untuk tanaman padi dengan member skor 1-9 (IRRI 2001 dalam Tubur 2011) seperti yang terlihat pada Tabel 1. 


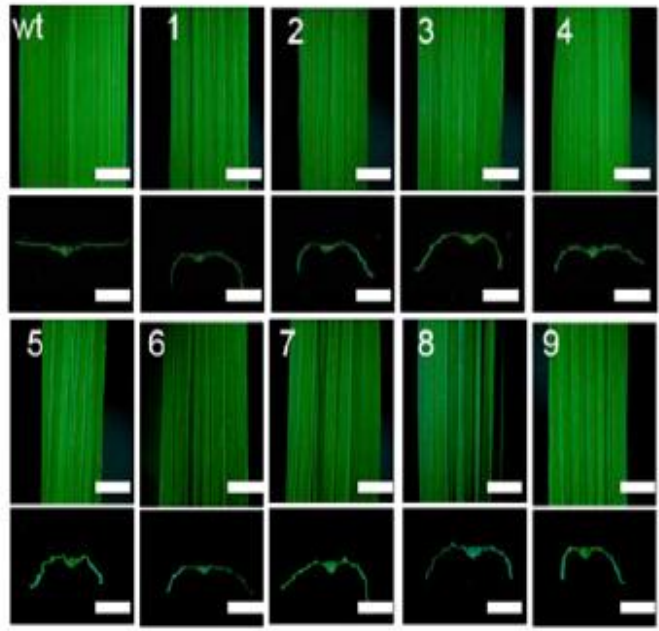

Gambar 1. Morfologi daun yang menunjukkan tingkat penggulungan daun (Zou et al., 2011)

Tabel 1. Nilai skor penggulungan daun (IRRI, 2001 dalam Tubur, 2011)

\begin{tabular}{ll}
\hline Skor & Penggulungan Daun \\
\hline 0 & $\begin{array}{l}\text { Daun sehat/daun tidak } \\
\text { menggulung }\end{array}$ \\
1 & $\begin{array}{l}\text { Daun mulai menunjukkan } \\
\text { lipatan }\end{array}$ \\
3 & Daun melipat bentuk huruf $\mathrm{V}$ \\
5 & Daun melipat bentuk huruf $\mathrm{U}$ \\
7 & Pinggiran daun saling \\
9 & bersentuhan-bentuk huruf $\mathrm{O}$ \\
\end{tabular}

Anatomi daun yang

menggulung (Gambar 3 dan 4) terjadi karena proses pengkerutan bulliform cell atau sel kipas. Sel kipas merupakan sederet sel yang lebih besar daripada sel epidermis lainnya, berdinding tipis, bervakuola besar dan berisi air. Fungsi sel kipas sendiri adalah melindungi jaringan di bawahnya agar tidak mengalami kerusakan akibat kehilangan air yang lebih besar serta membuka dan menutupnya daun dalam proses penggulungan daun (Zou et al. 2011).
Sel kipas ini mengandung banyak air, tanpa atau hampir tidak mengandung kloroplas dan hanya mempunyai sedikit atau bahkan tidak ada kutikula. Oleh sebab itu sel ini akan kehilangan air melalui transpirasi lebih cepat daripada sel epidermis lainnya. Saat terjadi kekurangan air, tekanan turgor pada sel ini menurun dan memungkinkan daun menggulung ke dalam (Salisbury dan Ross 1992; Kurniasih dan Wulandhany 2009).

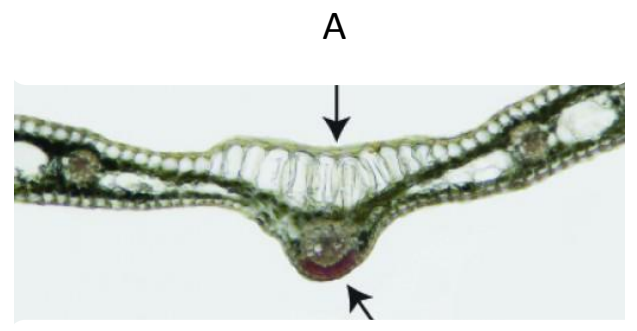

B

Gambar 3. Anatomi sel kipas atau bulliform cell. A. Sel kipas, B. Tulang daun bagian tengah (Alvarez et al. 2008)

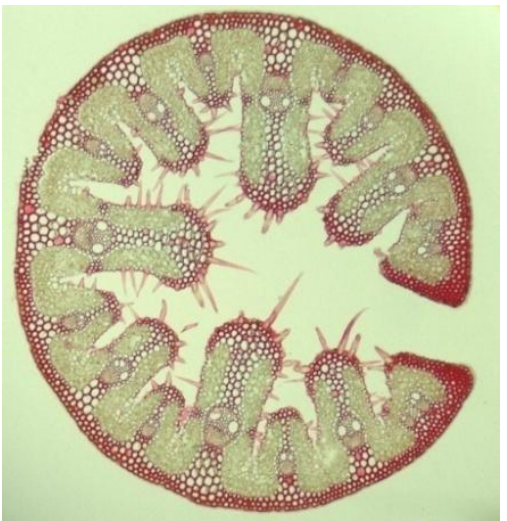

Gambar 4. Anatomi daun monokotil ketika terjadi penggulungan (Culbertson, 2012) 
Nio dan Lenak, Penggulungan daun .... 53

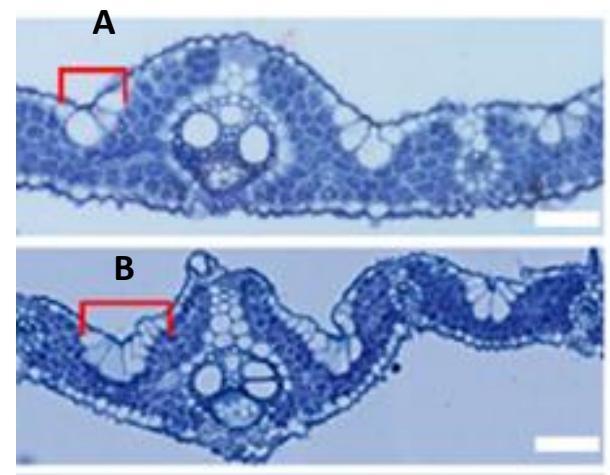

Gambar 5. Penampang melintang daun yang menunjukkan perbedaan jumlah dan ukuran sel kipas. A. Sel kipas pada daun normal, B. Sel kipas pada daun menggulung (Zou et al. 2011)

Sel kipas adalah sel epidermis yang terspesialisasi di permukaan bawah daun pada semua ordo pada tumbuhan Liliopsida kecuali Helobiae. Penyusutan sel kipas pada bagian permukaan bawah (adaxial) daun dekat tulang daun bagian tengah dikaitkan dengan penggulungan daun pada padi dan jenis rerumputan lainnya. Peningkatan jumlah dan ukuran dari sel kipas berkaitan dengan terjadinya penggulungan daun (Gambar 5).

Gen yang diduga kuat berperan dalam proses ini pada padi ialah gen Roc5 (Rice outermost cell-specific genes) yang mengkode homeodomain leucine zipper class IV transcriptional factor. Overexpression gen tersebut mengakibatkan daun menggulung pada sisi adaksial, sedangkan cosuppression gen ini menyebabkan penggulungan daun di sisi abaksial (Zou et al. 2011).

Terlambatnya penggulungan daun menunjukkan adanya usaha tanaman untuk mempertahankan turgor dalam upaya menghindari dehidrasi. Varietas padi yang mampu mempertahankan potensial air daun yang tetap tinggi pada saat kekurangan air cenderung mempunyai tingkat penggulungan daun yang lebih rendah (Kurniasih dan Wulandhany 2009). Berdasarkan hasil pengamatan visual dari penelitian Tubur (2011) padi varietas IR64 menunjukkan skor penggulungan daun tertinggi yaitu 9,00 (daun menggulung penuh) pada perlakuan kekeringan saat 3 MST (minggu setelah tanam) dan varietas Jatiluhur menunjukkan skor penggulungan daun terendah yaitu 3,00 dan 2,50 baik pada periode kekeringan 3 MST ataupun 6 MST. Tingginya skor penggulungan daun berkorelasi negatif dengan produksi varietas padi pada saat kekurangan air. Tanaman yang mempunyai skor penggulungan daun yang rendah dan potensial air tinggi merupakan tanaman yang resisten terhadap kekurangan air (Tubur et al. 2012).

Penggulungan daun pada padi gogo varietas Mentik, Sentani, IR 64, Ketan Gudel dan Cempo Grondol dipengaruhi oleh tinggi rendahnya kadar air tanah yang menghambat pertumbuhan tanaman. Di antara kelima varietas yang diuji, varietas Sentani memiliki skor penggulungan lebih tinggi dibandingkan varietas lainnya. Varietas ini lebih cepat melakukan pemeliharaan potensial air daunnya saat terjadi kekurangan air. Hal ini dilakukan untuk mengurangi evapotranspirasi yang berlebihan. Salah satu karakteristik padi gogo yang membedakannya padi sawah ialah daunnya yang cepat menggulung saat transpirasi tinggi (Kurniasih dan Wulandhany 2009).

\section{KESIMPULAN}

Penggulungan daun merupakan salah satu bentuk mekanisme drought avoidance pada tumbuhan monokotil dengan cara menurunkan laju evapotranspirasi atau dengan meningkatkan absorpsi air pada tanah 
kering untuk mempertahankan potensial air daun tetap tinggi. Sel kipas merupakan sel yang berperan dalam proses penggulungan daun, ketika tanaman mengalami kekurangan air terjadi peningkatan jumlah dan ukuran sel kipas sehingga bentuk dari daun akan berubah (menggulung). Tingkat penggulungan daun dapat ditentukan secara visual berdasarkan sistem standar evaluasi untuk tanaman padi dengan memberi skor 1-9. Rendahnya tingkat penggulungan daun berkorelasi positif dengan meningkatnya potensial air daun.

\section{DAFTAR PUSTAKA}

Adisyahputra, Sudarsono, Setiawan K (2011) Pewarisan sifat densitas stomata dan laju kehilangan air daun (rate leaf water loss RWL) pada kacang tanah (Arachis hypogaea L.). Jurnal Natur Indonesia 14 (1):73-89

Alvarez JM, Rocha JF, Machado SR (2008) Bulliform cells in Loudetiopsos chrysothrix (Nees) Conert and Tristachya lerostachya Nees (Poaceae): structure in relation to function. http://www.scielo.br/scielo.php ?pid=S1516-

$89132008000100014 \&$ script $=\mathrm{s}$ ci_arttext. Diakses pada 8 Oktober 2013

Bouman BAM, Tuong TP (2001) Field water management to save water and increase its productivity in irrigated rice. Agric Water Manage 49:11-30

Campbell NA, Reece JB, Urry LA, Cain MA, Wasserman SA, Minorsky PV, Jackson RB (2012) Biologi Jilid 2 (Terjemahan) Edisi ke-8. Erlangga. Jakarta
Culbertson Ed (2012) Labprac 1.1. http://www.studyblue.com/note s/note/n/labprac11/deck/22266 41. Diakses pada 8 Oktober 2013

Bray EA (1997) Plant resources to water deficit. Trend in Plant Sci 2:48-54

Darusman LK, Koswara O, Wiroatmodjo J, Arsjad A (1991) Pengaruh stress air dan $\mathrm{pH}$ tanah terhadap kemungkinan timbulnya senyawaan stress pada tanaman kentang (Solanum tuberosum L.). Forum Pascasarjana 14 (1):13-23

Fitter AH, Hay RKM (1991) Fisiologi lingkungan tanaman. Gadjah Mada University Press, Yogyakarta

Hardjowigeno S, Widiatmaka (2007) Evaluasi kesesuaian lahan dan perencanaan tataguna lahan. Gadjah Mada University Press, Jakarta

Harwati TC (2007) Pengaruh kekurangan air (water deficit) terhadap pertumbuhan dan perkembangan tanaman tembakau. Jurnal Inovasi Pertanian 6 (1):44-51

Haryati (2008) Pengaruh cekaman air terhadap pertumbuhan dan hasil tanaman. http://library.usu.ac.id/downloa $\mathrm{d} / \mathrm{fp} / \mathrm{hs}$ Ipertanian-haryati2.pdf. Diakses pada 8 Oktober 2013

Jadid M N (2007) Uji toleransi aksesi kapas (Gossypium hirsutum L.) terhadap cekaman kekeringan dengan menggunakan polietilena glikol (PEG). Skripsi. Fakultas Sains dan Teknologi Universitas Islam Negeri Malang, Malang

Jones MM, Turner NC, Osmond CB (1981) Mechanisms of drought resistance. Dalam: Paleg LG, 
Aspinall D (ed) The physiology and biochemistry of drought resistance in plants, Academic Press, Sydney, pp 15-37

Jordan WR, Dugas WR, Shouse PJ (1983) Strategies for crop improvement for drought-prone regions. Agric Water Manag 7:281-299

Kurniasih B, Wulandhany F (2009) Penggulungan daun, pertumbuhan tajuk dan akar beberapa varietas padi gogo pada kondisi cekaman air yang berbeda. Agrivita 31 (2): 118128

Levitt J (1980) Responses of plants to environmental stresses. II Water, radiation, salt and other stresses. 2nd Ed. Academic Press, New York

Mitra J (2001) Genetics and genetic improvement of drought resistance in crop plant. Current Science 80 (6):758763

Nio SA, Siregar AH, Widiyanto SN (1997) Aktivitas peroksidase pada lini kalus padi (Oryza sativa L.) toleran kekeringan. Eugenia 3:102-108
Nio SA (2011) Toleransi tumbuhan terhadap kekeringan dengan penyesuaian osmotik. Makalah disampaikan dalam Orasi IImiah pada Dies Natalis ke-13 FMIPA UNSRAT Manado. 16 April 2011

Salisbury F B, Ross CW (1992) Plant Physiology, $4^{\text {th }}$ Ed. Wadsworth Publishing California

Tubur HW (2011) Respon beberapa genotipe padi terhadap periode kekeringan pada sistem sawah. Tesis. Sekolah Pascasarjana. IPB. Bogor

Tubur HW, Chozin MA, Santosa E, Junaedi A (2012) Respon agronomi varietas padi terhadap periode kekeringan pada sistem sawah. J Agron Indonesia 40 (3): 167 - 173

Zou Liang-ping, Sun Xue-hui, Zhang Zhi-guo, Liu Peng, Wu Jin-xia, Tian Cai-juan, Qiu Jin-long, Lu Tie-gang (2011) Leaf rolling controlled by the homeodomain leucine zipper class IV gene Roc5 in rice. Plant Physiology 156:15891602 